\title{
Analisa Kuat Lentur Balok Beton Bertulang dengan Menggunakan Profil Baja Ringan sebagai Tulangan
}

\section{Analysis of Bending Strength of Reinforced Concrete Beams Using Mild Steel Profiles As Reinforcement}

\author{
Sari Utama Dewi ${ }^{*}$, Ahmat Suandi \\ ${ }^{1,2}$ Universitas Muhammadiyah Metro \\ Email: saridewi.dewi1981@gmail.com ${ }^{(1)}$,ahmadsuandi30@gmail.com ${ }^{(2)}$
}

\begin{abstract}
Abstrak
Pengembangan rekayasa teknologi pada saat ini terasa begitu cepat. Dengan perkembangan teknologi saat ini kita dapat membuat bangunan yang memiliki keunggulan dan keuntungan, salah satunya adalah beton bertulang yang menggunakan tulangan baja ringan. Penggunaan baja ringan ini sebagai pengganti tulangan pada beton masih belum populer di Indonesia. Pada penelitianini akan menggunakan tulangan baja ringan kanal C sebagai tulangan struktur balok beton. Tujuan dari penelitian adalah untuk menganalisis perbedaan kuat lentur balok beton menggunakan tulangan baja ringan dengan balok beton menggunakan tulangan baja tulangan serta menghitung perbedaan nilai kekakuannya. Penelitian ini dilaksanakan melalui beberapa tahap yaitu : pengadaan bahan dan peralatan, pemeriksaan bahan dan peralatan, perencanaancampuran beton, pembuatan beton, perawatan beton (curing), pengujian beton dan analisis hasil penelitian. Dari keempat sampel dengan 2 perbandingan tulangan yang telah diuji didapat nilai kuat lentur rata-rata pada sampel baja ringandesain B yaitu 11,816 Mpa dan baja tulangan didapat nilai kuat lentur 9,993 Mpa, sehingga dengan hasil yang telah didapat ini maka baja ringan kanal $\mathrm{C}$ dapat digunakan sebagai alternatif pengganti pada tulangan baja tulangan kususnya pada balok dengan dimensi $15 \times 15 \mathrm{~cm}$.
\end{abstract}

Kata Kunci : Profil Baja Ringan Kanal C, Kuat Lentur

\begin{abstract}
The development of engineering technology at this time feels so fast. With current technological developments, we can create buildings that have advantages and disadvantages, one of which is reinforced concrete using mild steel reinforcement. The use of mild steel as a substitute for reinforcement in concrete is still not popular in Indonesia. In this study, $C$ channel mild steel reinforcement will be used as reinforcement for the concrete beam structure. The purpose of the study was to analyze the difference in flexural strength of concrete beams using mild steel reinforcement and concrete beams using steel reinforcement and to calculate the difference in stiffness values. This research was carried out through several stages, namely: procurement of materials and equipment, inspection of materials and equipment, planning of concrete mixtures, concrete manufacture, concrete treatment (curing), concrete testing and analysis of research results. From the four samples with 2 comparisons of reinforcement that have been tested, the average flexural strength value in the design B mild steel sample is 11,816 Mpa and the reinforcing steel has a flexural strength value of $9.993 \mathrm{Mpa}$, so that with these results, $C$ channel mild steel can be used. as an alternative to steel reinforcement, especially in beams with dimensions of $15 x 15 \mathrm{~cm}$.
\end{abstract}

Keyword : C Channel Mild Steel Profile, Flexural Strength 


\section{PENDAHULUAN}

Beton merupakan unsur yang penting, terutama fungsinya sebagai pembentuk struktur yang sering digunakan. Dengan perkembangan teknologi saat ini kita dapat membuat bangunan yang memiliki keunggulan dan keuntungan.

Beton yang bermutu baik mempunyai beberapa kelebihan diantaranya mempunyai kuat tekan tinggi, tahan terhadap pengkaratan atau pembusukan oleh kondisi lingkungan, tahan terhadap cuaca (panas, dingin, sinar matahari, hujan). Beton juga mempunyai beberapa kelemahan, yaitu lemah terhadap kuat tarik, mengembang dan menyusut bila terjadi perubahan suhu, sulit kedap air secara sempurna, dan bersifat getas [1].

Beton bertulang sebagai elemen balok umumnya diberi tulangan memanjang (lentur) dan tulangan sengkang (geser). Tulangan lentur untuk menahan beban lentur yang terjadi pada balok, sedangkan tulangan geser untuk menahan gaya geser. Balok beton merupakan bagian dari struktur bangunan yang berfungsi untuk menopang lantai diatasnya, balok juga berfungsi sebagai penyalur momen menuju kolom-kolom. Beton dan baja merupakan dua jenis material struktur yang umum digunakan dalam konstruksi suatu bangunan. Kedua jenis material tersebut kadang kala saling membantu satu sama lain, namun bisa juga berdiri sendiri-sendiri, sehingga banyak struktur dengan bentuk dan fungsi yang serupa dapat dibangun dengan beton atau baja. Beton merupakan material yang relatif kuat terhadap beban tekan tetapi lemah terhadap beban tarik. Untuk memperoleh struktur bangunan yang relatif kuat terhadap beban tarik, maka ditambahkan baja tulangan di dalamnya. Kombinasi antara beton dan baja tulangan tersebut dikenal dengan nama beton bertulang sebagai struktur yang optimal pada konstruksi suatu bangunan. Hal ini bukan karena sifat mekaniknya saja yang relatif baik, tetapi beton bertulang juga memiliki sifat tahan lama [2].

Balok dikenal juga sebagai elemen struktur lentur, sehingga balok lebih dominan menahan gaya dalam bentuk momen lentur dan geser [3].

Pada penelitian ini akan menggunakan profil baja ringan kanal $\mathrm{C}$ sebagai unsur pengganti penahan gaya tarik pada struktur balok beton dimana diuji kuat lentur dan direncanakan akan tetap kuat serta mampu menahan beban yang dipikul.

\section{LANDASAN TEORI}

\section{Definisi Beton}

Beton adalah campuran semen Portland atau semen hidrolis lainnya, agregat halus, agregat kasar, dan air, dengan atau tanpa bahan tambahan (admixture). Pengelompokan jenis agregat yang umum adalah [4] :

a. Agregat halus

b. Agregat kasar

\section{Sifat-sifat Umum Beton}
a. Kekuatan
b. Keawetan (Durability)
c. Modulus Elastisitas
d. Kelecakan (Workability)
e. Susut (Shrinkage)
f. Pemisahan Agregat Kasar (Segregation)
g. Bleeding

\section{Kelebihan Beton}

a) Dapat dengan mudah mendapatkan material dasarnya (availability)

b) Kemudahan untuk digunakan (versatility) 
c) Kemampuan beradaptasi (adaptability) sehingga beton dapat dicetak dengan bentuk dan ukuran berapapun

d) Tahan terhadap temperatur tinggi, biaya pemeliharaan yang kecil.

e) Mampu memikul beban yang berat

\section{Kekurangan}

a) Berat sendiri beton yang besar, sekitar $2400 \mathrm{~kg} / \mathrm{m} 3$. Kekuatan tariknya rendah, meskipun kekuatan tekannya besar

b) Beton cenderung untuk retak, karena semennya hidrolis. Baja tulangan bisa berkarat, meskipun tidak terekspose separah struktur baja

c) Kualitasnya sangat tergantung cara pelaksanaan dilapangan.

d) Struktur beton sulit untuk dipindahkan.

\section{Beton Bertulang}

a. Kelebihan Beton Bertulang

1) Memiliki kekuatan tekan yang relatif lebih tinggi dari pada kebanyakan bahan lainnya

2) Struktur beton bertulang sangat kokoh tahan terhadap api dan air dan tidak memerlukan biaya pemeliharaan yang tinggi.

3) Dibanding dengan bahan lain, beton bertulang memiliki masa layan yang sangat panjang.

b. Kelemahan Beton Bertulang

1) Beton memiliki kekuatan tarik yang sangat rendah sehingga memerlukan penggunaan tulangan tarik.

2) Beton bertulang memerlukan begisting untuk menahan beton tetap pada tempatnyan sampai beton mengeras.

3) Rendahnya kekuatan per satuan berat dari beton menyebabkan beton bertulang menjadi berat. Ini akan berpengaruh terutama pada struktur dengan bentang-bentang panjang dimana beban mati akibat berat sendiri yang sangat besar akan mempengaruhi momen lentur.

Baja Tulangan yang Tersedia di pasaran ada 2 jenis yaitu [5]:

1) Baja Tulangan Polos ( BJTP)

Tulangan Polos biasanya digunakan untuk tulangan geser/begel/sengkang, dan mempunyai tegangan leleh (fy) minimal sebesar $240 \mathrm{MPa}$ (disebut BJTP-24).

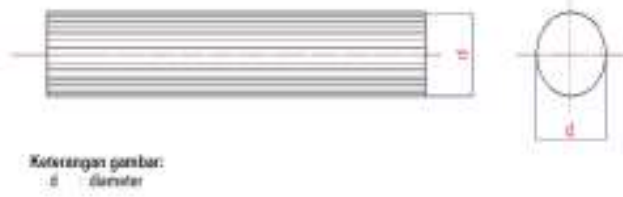

Gambar 1. Baja Tulangan Polos (Sumber : SNI 2052:2017)

2) Baja Tulangan Ulir Deform (BJTD)

Tulangan Ulir/deform digunakan untuk untuk tulangan longitudinal atau tulangan memanjang, dan mempunyai tegangan leleh (fy) minimal $300 \mathrm{MPa}$ (disebut BJTD-30).
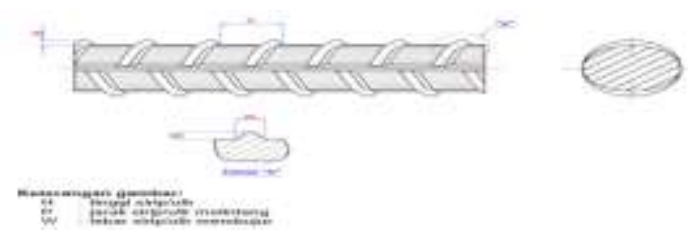

Gambar 2. Baja Tulangan Ulir (Sumber : SNI 2052:2017)

a. Kelebihan Baja Tulangan :

1) Kuat tarik tinggi.

2) Tidak dimakan rayap

3) Hampir tidak memiliki perbedaan nilai muai dan susut

4) Bisa di daur ulang

5) Dibanding stainless steel lebih murah

6) Dibanding beton lebih lentur dan lebih ringan

7) Dibanding alumunium lebih kuat

b. Kekurangan Baja Tulangan :

1) Bisa berkarat.

2) Lemah terhadap gaya tekan. 
3) Tidak fleksibel seperti kayu yang dapat dipotong dan dibentuk berbagai profil

4) Tidak kokoh

5) Tidak tahan api

Desain tulangan yang akan digunakan pada penelitian ini adalah :

Tulangan Pokok Tulangan Geser Jarak tulangan geser Selimut Beton
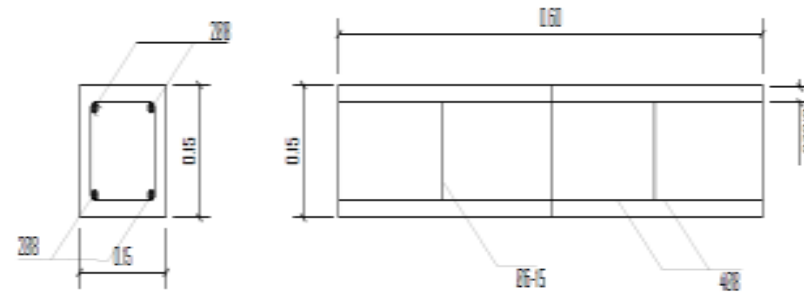

Gambar 3. Desain Penulangan Baja Tulangan $4 \varnothing 8$ $\varnothing 6-15$

\section{Profil Baja Ringan}

Profil baja ringan digunakan secara umum pada pembuatan rangka atap rumah sebagai material kuda-kuda. Walaupun pada perkembanganya baja ringan banyak mengalami perlakuan inovasi yang baik, dan menjadikan efisien pada beberapa pekerjaan seperti pembuatan kusen, pembuatan partisi dinding, bahkan bisa digunakan sebagai pilar atau kerangka/kolom sebuah bangunan [6].

Baja ringan merupakan material yang memiliki bahan dasar carbon steel dengan jumlah karbon berkisar $0.05 \%-0.25 \%$ dari beratnya. Jumlah karbon yang rendah tersebut disebut sebagai baja karbon rendah. Sedangkan, kandungan karbon dari 0,30\%-2,0\% disebut sebagai baja karbon tinggi. Rendahnya karbon menunjukkan bahwa baja ringan mampu menghasilkan kekuatan tarik yang lebih sedikit dibandingkan dengan baja karbon tinggi. bentuk baja ringan bermacam-macam dan memiliki kegunaannya masing-masing.

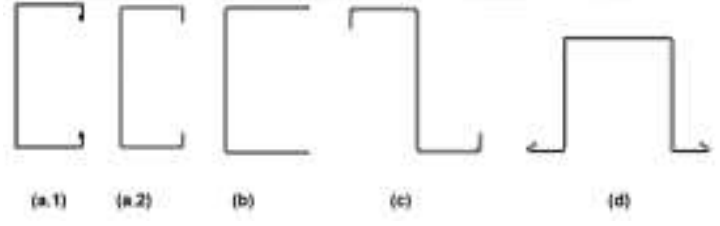

Gambar 4. Macam-macam Bentuk Baja Ringan (Sumber : SNI 2052:2017)

$$
\begin{aligned}
& \text { Keterangan : } \\
& \begin{array}{ll}
\text { a.1 } & =\text { Profil C dengan lipatan } \\
\text { a.2 } & =\text { Profil C tanpa lipatan } \\
\text { b } & =\text { Profil } \mathrm{U} \\
\text { c } & =\text { Profil Z } \\
\text { d } & =\text { Profil topi }
\end{array}
\end{aligned}
$$

Salah satu bentuk baja ringan yaitu kanal C. Kanal C memiliki bentuk yang sesuai dengan huruf $\mathrm{C}$ dan ukurannya dibedakan sesuai dengan ukuran ketebalannya. Ukuran ketebalan bentuk baja ringan kanal $\mathrm{C}$ umumnya yaitu 0.60 $\mathrm{mm}, 0,75 \mathrm{~mm}$ dan $1 \mathrm{~mm}$. Ukuran ketebalan yang bermacam-macam difungsikan untuk hal yang berbeda pula. Pada umumnya, kanal C dengan ukuran $0.75 \mathrm{~mm}$ digunakan untuk pembuatan kuda-kuda pada atap dengan beban yang ringan. Misalnya saja genteng metal, asbes, spandek dan atap ringan lainnya. Kanal C 75 x 0,75 juga bisa digunakan untuk dudukan plafon, gordin, kolom profil bangunan serta partisi dinding dan jendela.

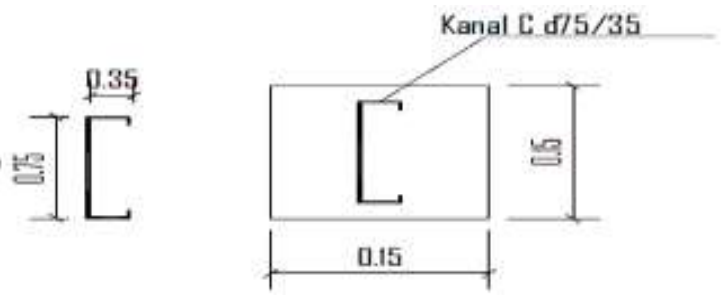

Gambar 5. Baja Ringan Kanal C 75 (Sumber : Perencanaan Penelitian, 2020)

a. Kelebihan Baja Ringan 
1) Memiliki kekuatan tarik yang tinggi namun ringan.

2) Sifatnya liat/tangguh serta memiliki daktilitas yang bagus

3) Mempunyai sifat yang seragam karena diproduksi pabrik

4) Tahan terhadap serangan rayap sehingga lebih tahan lama.

5) Tahan terhadap karat.

6) Proses pemasangan baja ringan relatif cepat

b. Kekurangan Baja Ringan

1) Harga materialnya masih termasuk mahal.
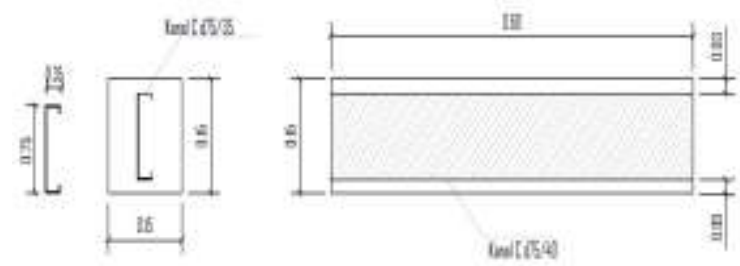

Gambar 8. Desain Perletakkan Baja Ringan C (Sumber : Perencanaan Penelitian, 2020)

\section{Rencana Campuran Beton (mix design)}

Dalam penelitian ini rencana campuran beton menggunakan rencana mix design metode SK.SNI 02-6820-2002. Kuat tekan beton yang direncanakan adalah $20.75 \mathrm{Mpa}$ (K 250) dan nilai slump test 8 - $12 \mathrm{~cm}$ [7].

2) Sulit menyatu dengan beton

3) Rentan roboh apabila salah pemasangannya

4) Dimensinya sudah ditetapkan sehingga tidak bisa di ubah

Adapun beberapa desain perletakkan baja ringan untuk pengujian yaitu:

1) Desain Baja Ringan $A$
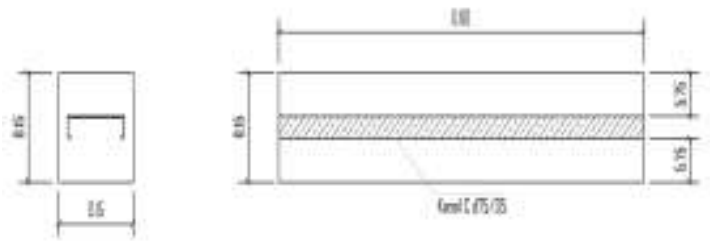

Gambar 6. Desain Perletakkan Baja Ringan A (Sumber : Perencanaan Penelitian, 2020)

2) Desain Baja Ringan B
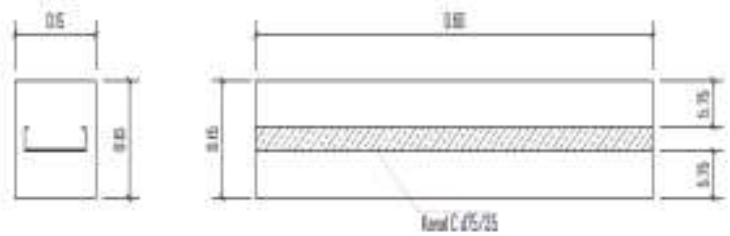

Gambar 7. Desain Perletakkan Baja Ringan B (Sumber : Perencanaan Penelitian, 2020)

3) Desain Baja Ringan $C$

\section{Pengujian Nilai Slump Test}

a. Slump test beton adalah pengujian kekentalan beton segar agar beton yang diproduksi dapat mencapai kekuatan mutu beton dan mendapatkan nilai slump beton yang baik.

b. Fungsi lain dari uji slump beton adalah agar beton yang diproduksi di batching plan akan dengan sesuai rencana kerja dari sebuah bangunan yang dibangun.

\section{Perawatan Beton (curing)}

Tujuan pelaksanaan curing / perawatan beton adalah memastikan reaksi hidrasi senyawa semen termasuk bahan tambahan atau pengganti supaya dapat berlangsung secara optimal sehingga mutu beton yang diharapkan dapat tercapai, dan menjaga supaya tidak terjadi susut yangberlebihan pada beton akibat kehilangan kelembaban yang terlalu cepat atau tidak seragam, sehingga dapat menyebabkan retak.

Pelaksanaan curing/perawatan beton dilakukan segera setelah beton mengalami atau memasuki fase hardening (untuk permukaan beton yang terbuka) atau setelah pembukaan cetakan / acuan / bekisting, selama durasi tertentu yang dimaksudkan untuk memastikan terjaganya kondisi yang 
diperlukan untuk proses reaksi senyawa kimia yang terkandung dalam campuran beton.

\section{Kuat Lentur Balok}

Besarnya kuat lentur balok dapat diketahui menggunakan alat uji kuat lentur seperti gambar di bawah ini [8]:

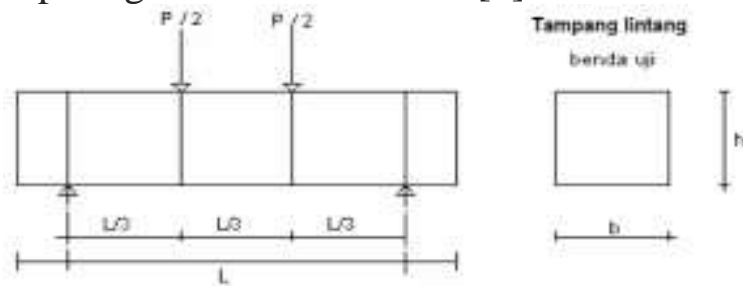

Gambar 9. Alat Uji Kuat Lentur ( Sumber : SNI 4431:2011)

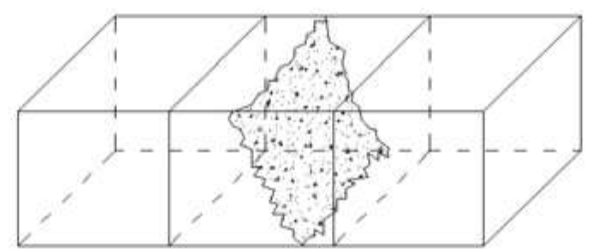

Gambar 10. Balok Patah Pada 1/3 Bidang Tengah (Sumber :SNI 4431:2011)

$$
\sigma l=\frac{P \cdot L}{b \cdot h^{2}}
$$

\section{Kekakuan Balok}

Analisis kekakuan balok secara teoritis.

Keterangan :

$$
\mathrm{K}=\frac{48 \cdot \text { Ec.Iteoritis }}{\mathrm{L}^{2}}
$$

$\begin{array}{ll}\mathrm{K} & : \text { Kekakuan balok }(\mathrm{N}) \\ \mathrm{Ec} & : \text { Modulus elastisitas } \\ \mathrm{L} & : \text { Panjang bentang }(\mathrm{m}) \\ \text { Iteoritis } & : \text { Momen inersia }\left(\mathrm{m}^{4}\right)\end{array}$

\section{Penelitian Terdahulu}

Penelitian terdahulu yang telah dilakukan oleh Yuyu dkk pada tahun 2020 mengenai Kapasitas Lentur Balok Komposit Beton Dengan Baja Ringan. Penelitian ini dilakukan dengan pengujian kuat lentur pada balok beton bertulang dengan mutu beton $17 \mathrm{MPa}$ yang dibebani 2 titik pembebanan. Benda uji terdiri dari 4 variasi; dimana variasi A adalah balok dengan tulangan baja konvensional (rangkap), variasi B adalah balok dengan tulangan baja ringan (rangkap), variasi $\mathrm{C}$ adalah balok dengan tulangan baja ringan (tunggal), dan variasi D adalah kombinasi tulangan baja konvensional di daerah tekan dan baja ringan di daerah tarik. Disimpulkan bahwa balok variasi A memiliki nilai kuat lentur dan momen lentur yang lebih besar dengan nilai lendutan yang lebih kecil dibandingkan dengan balok variasi B, C, dan D [9].

Muslimin dkk pada tahun 2021 melakukan penelitian mengenai Uji Lentur Balok Beton Bertulang Baja Ringan Dengan Skema Tulangan Tunggal. Tujuan penelitian ini yaitu untuk mengetahui kapasitas lentur balok beton berbaja ringan dengan memanfaatkan baja ringan sebagai tulangan longitudinal. Hasil uji lentur menunjukkan bahwa skema 1 menunjukkan kuat lentur terbesar dari skema lainnya yaitu sebesar 7.48 Mpa [3].

Tumcala pada tahun 2017 melakukan penelitian mengenai Tinjauan Kinerja Balok Beton Bertulang Tampang Empat Persegi Panjang dengan Tulangan dari Profil Baja Ringan. Penelitian ini tentang perbandingan kinerja kuat lentur antara balok beton bertulang dengan profil dari baja ringan kanal $U$ dan balok beton bertulang dengan profil dari baja konvensional. Pengujian menggunakan metode pengujian kuat lentur dan kemudian sampel dihitung nilai kekakuan, beban retak awal dan beban ultimate dengan menggunakan metode teoritis dan eksperimen. Disimpulkan bahwa balok A mampu menahan beban ultimate dan nilai kekakuan yang lebih besar di bandingkan dengan balok $\mathrm{B}$ dan $\mathrm{C}$, akan tetapi nilai retak awalnya mempunyai nilai yang lebih kecil [6].

Loliandy pada tahun 2014 melakukan penelitian mengenai Studi Eksperimental Kuat Lentur pada Balok Beton Bertulang dengan Perkuatan Baja Ringan Profil U. 
Pada penelitian ini digunakan baja ringan profil U sebagai bahan alternatif untuk perkuatan lentur pada balok beton bertulang yang diharapkan dapat meningkatkan kekuatan struktur tersebut. Perkuatan dilakukan pada daerah tarik dengan menggunakan baja ringan profil $U$ dengan sambungan baut. Penelitian ini dilakukan dengan 3 (tiga) balok beton bertulang, dimana 1 (satu) balok beton bertulang normal dan 2 (dua) lainnya berupa balok beton bertulang dengan perkuatan baja ringan profil $\mathrm{U}$. Pengujian balok dilakukan di atas 2 (dua) perletakan sendi dan rol untuk pengujian kuat lentur, regangan, lendutan, dan retak. Hasil pengujian balok dengan perkuatan baja ringan profil $U$ TS.40.45 menunjukkan terjadi penurunan lendutan sebesar 20,04 \%, penurunan regangan beton ( $(\mathrm{Es})$ sebesar $8,38 \%$ dan penurunan regangan tulangan baja tarik $(\mathcal{E} s)$ sebesar 7,55 \% [10].

\section{METODOLOGI PENELITIAN}

Tahapan dalam penelitian ini dapat dilihat pada gambar diagram alir berikut.

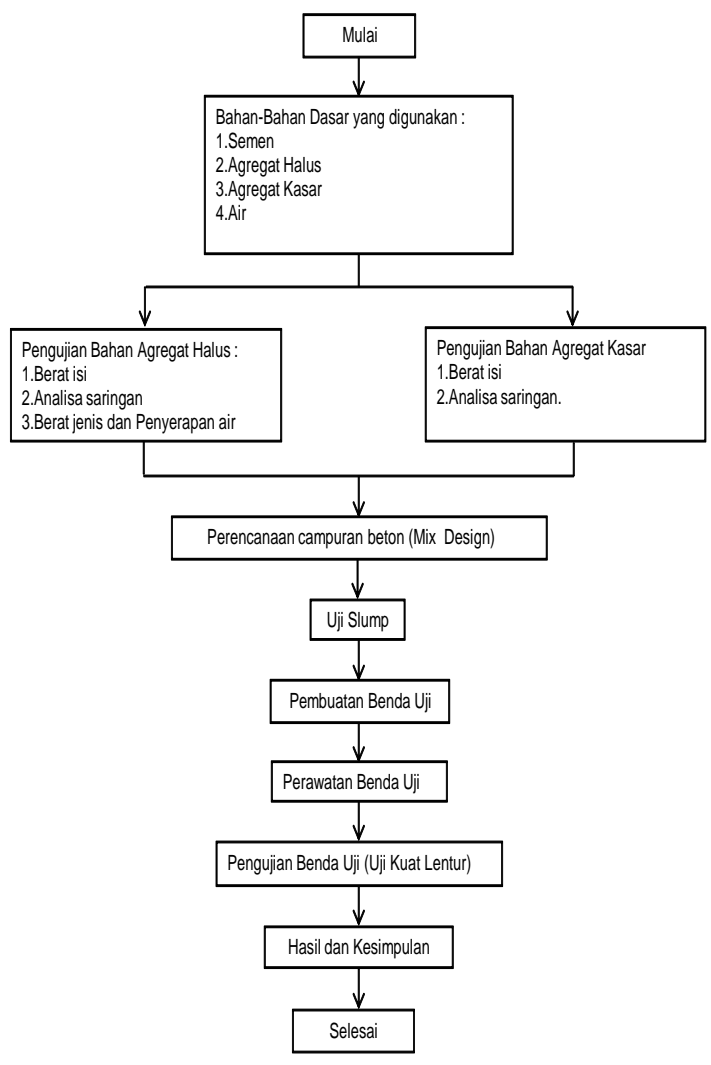

Gambar 11. Bagan Alir Penelitian

HASIL DAN PEMBAHASAN

1. Perhitungan Mix Design dengan Metode SK.SNI.T-15-1990-03 [11].
a. Semen
$=348,2 \mathrm{~kg}$
b. Agregat halus
$=914,3 \mathrm{~kg}$
c. Agregat kasar
$=1117,5 \mathrm{~kg}$
d. Air
$=195$ liter
Jumlah
$=2575,00 \mathrm{~kg} / \mathrm{m}^{3}$

Untuk kebutuhan beton cetakan 0,0135 $\mathrm{m}^{3}$
a. Semen
$=348,2 \times 0,0135$
$=5,1867 \mathrm{~kg}$
b. Agregat halus $=914,3 \times 0,0135$
$=12,343 \mathrm{~kg}$
c. Agregat kasar $=1117,5 \times 0,0135$
$=15,086 \mathrm{~kg}$
d. Air
$=195 \times 0,0135$
$=2,632$ liter 
2. Pengujian Agregat Halus

Tabel 1. Hasil Pengujian Agregat Halus

\begin{tabular}{clc}
\hline No & \multicolumn{1}{c}{ Pengujian Agregat Halus } & Hasil \\
\hline 1. & Berat volume agregat halus & $0,957 \mathrm{gram} / \mathrm{cm}^{3}$ \\
2. & Kadar lumpur agregat halus & $12,37 \%$ \\
3. & Kadar air agregat halus & $1,95 \%$ \\
4. & Penyerapan & $1,33 \%$ \\
5. & Berat jenis kering permukaan (SSD) & 2,59 \\
\hline
\end{tabular}

Modulus Kehalusan $(\mathrm{FM})=2,70$

Pasir ini memenuhi syarat SK.T SNI-151990-03

\section{Pengujian Agregat Kasar}

Tabel 2. Hasil Pengujian Agregat Kasar

\begin{tabular}{clc}
\hline No & \multicolumn{1}{c}{ Pengujian Agregat Kasar } & Hasil Pengujian \\
\hline 1. & Berat volume agregat kasar & $0,942 \mathrm{gram} / \mathrm{cm}^{3}$ \\
2. & Kadar lumpur agregat kasar & $2,24 \%$ \\
3. & Kadar air agregat kasar & $1,96 \%$ \\
4. & Penyerapan & $1,04 \%$ \\
5. & Berat jenis kering permukaan (SSD) & 3,41 \\
\hline
\end{tabular}

Modulus Kehalusan $(\mathrm{FM})=2,745$

Agregat ini memenuhi syarat SK.T SNI-151990-03 [12]

4. Pengujian Slump Test

Tabel 3. Hasil Pengujian Slump Test

\begin{tabular}{cccc}
\hline No. & Beton & Peruntukkan & $\begin{array}{c}\text { Slump } \\
(\mathrm{cm})\end{array}$ \\
\hline 1. & Mix Concrete 1 & Kanal A & 8,45 \\
2. & Mix Concrete 2 & Kanal B & 8 \\
3. & Mix Concrete 3 & Kanal C & 8,3 \\
4. & Mix Concrete 4 & Baja Tulangan & 8,27 \\
\hline
\end{tabular}

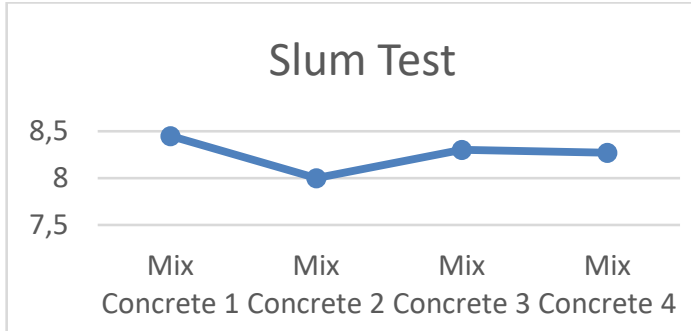

Gambar 12. Diagram. Grafik Slump Test

5. Kuat Lentur Beton Umur 28 Hari (Balok)
Hasil Pengujian Kuat Lentur dapat dilihat pada gambar diagram di bawah ini :
a. Desain Baja Ringan A

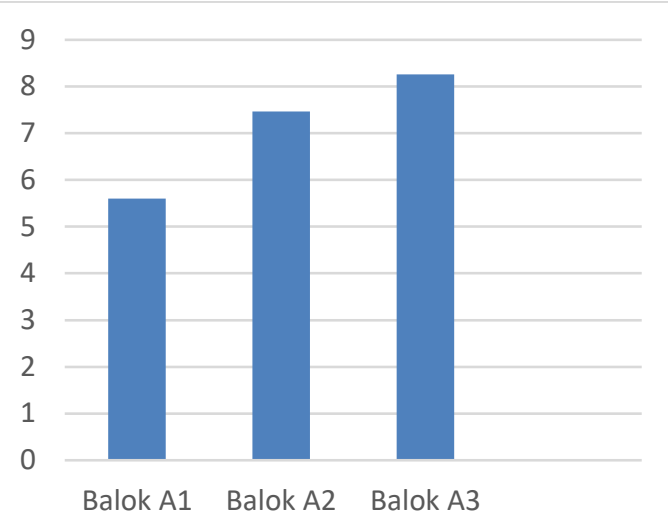

Gambar 13. Diagram Batang Kuat Lentur Beton Desain A

\section{b. Desain Baja Ringan B}

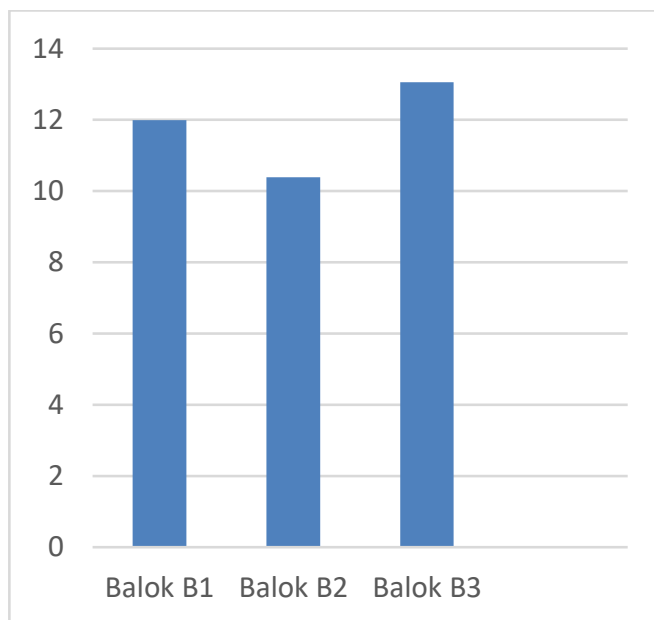

Gambar 14. Diagram Batang Kuat Lentur BetonDesain B

c. Desain Baja Ringan C 


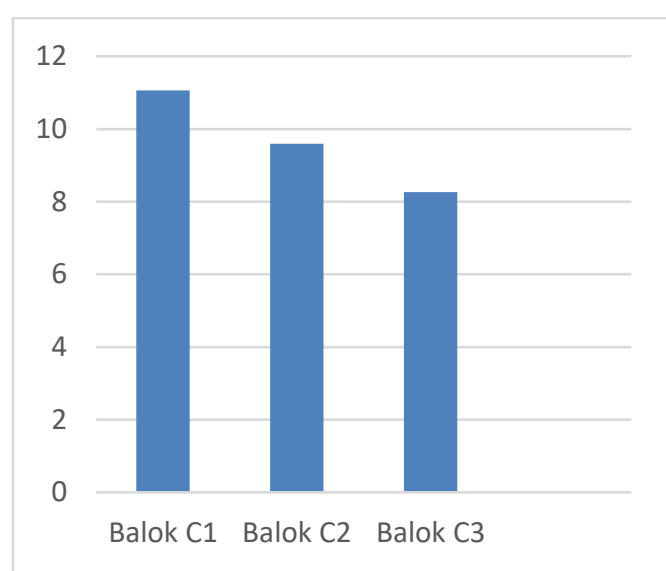

Gambar 15. Diagram Batang Kuat Lentur Beton Desain C

\section{d. Baja Tulangan}

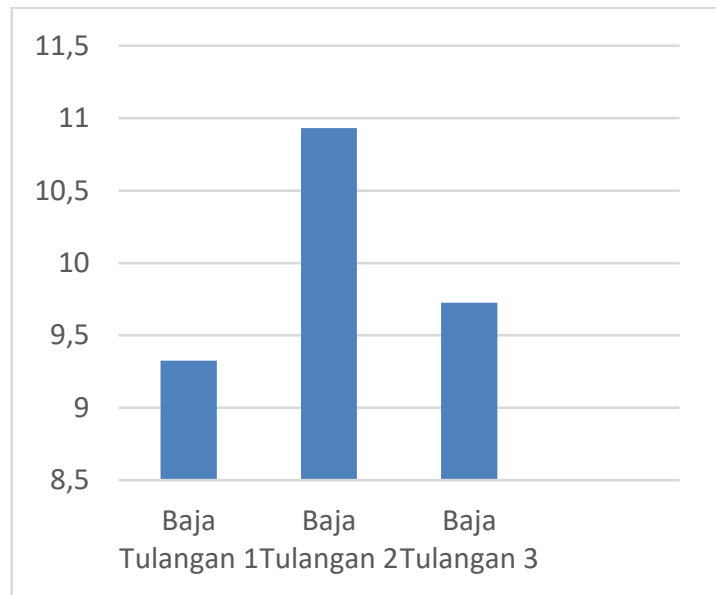

Gambar 16. Diagram Batang Kuat Lentur Beton Baja Tulangan

e. Rekapitulasi Hasil Perhitungan Kuat Lentur

Tabel 4. Hasil Rekapitulasi Perhitungan Kuat Lentur

\begin{tabular}{cc}
\hline No. Benda Uji & Kuat Lentur Rata-Rata (Mpa) \\
\hline Balok A & 7,107 \\
Balok B & 11,816 \\
Balok C & 9,638 \\
BalokTulangan & 9,993 \\
\hline
\end{tabular}

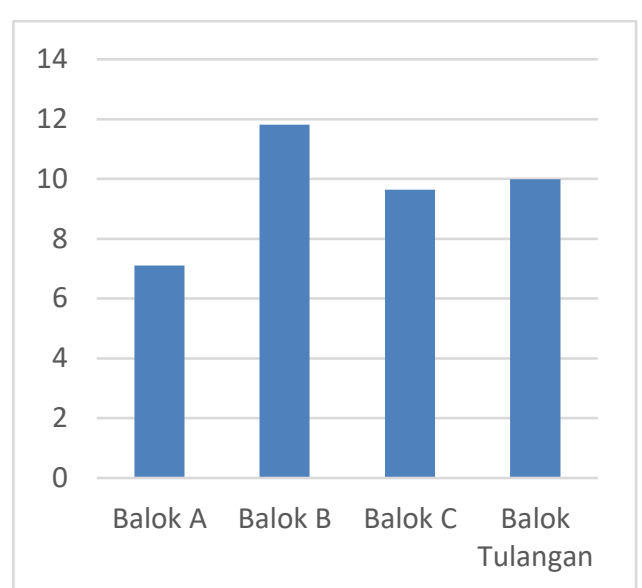

Gambar 17. Diagram Batang Kuat Lentur Beton Rata-rata

Tabel 5. Hasil Rekapitulasi Nilai Kekakuan RataRata

\begin{tabular}{lc}
\hline \multicolumn{1}{c}{ No Uji Benda } & Nilai Kekakuan Rata-Rata \\
\hline Balok A & $(\mathbf{N})$ \\
Balok B & $11,92 \times 10^{6}$ \\
Balok C & $20,16 \times 10^{6}$ \\
Baja Tulangan & $11,20 \times 10^{6}$ \\
\hline
\end{tabular}

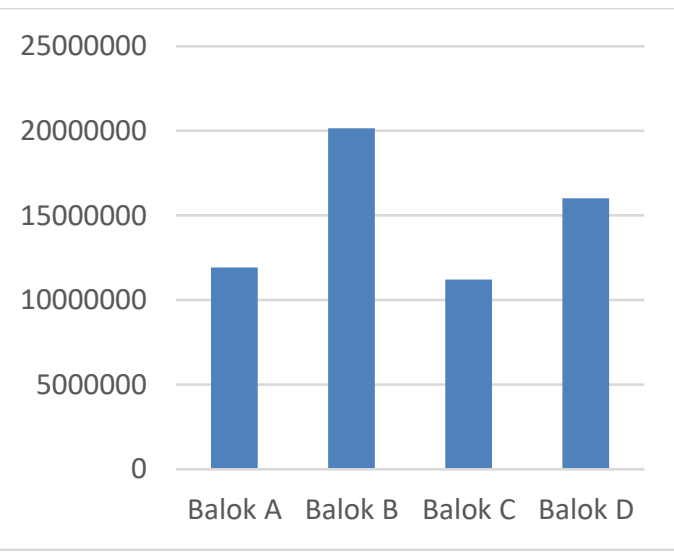

Gambar 18. Diagram Batang Rekapitulasi Nilai Kekakuan

Dari hasil pengujian kuat lentur yang sudah dilakukan bisa diketahui bahwa Balok beton dengan menggunakan profil baja ringan dengan desain $\mathrm{B}$ memiliki nilai kuat lentur yang paling tinggi dengan nilai rata-rata 11.816 sedangkan kuat lentur Balok beton dengan menggunakan baja tulangan mendapatkan nilai kuat lentur dengan nilai 9,993 Mpa, nilai kuat lentur 
balok beton dengan menggunakan baja ringan dengan desain $\mathrm{C}$ memiliki nilai kuat lentur 9,638 dibawah nilai kuat lentur baja tulangan dan yang terakhir balok beton dengan menggunakan baja ringan desain $\mathrm{A}$ memiliki nilai yang terkecil yaitu 7,107 Mpa.

Dari hasil pengujian kuat lentur yang sudah dilakukan bisa diketahui berapa nilai kekakuan dari balok beton tersebut. Balok beton dengan menggunakan profil baja ringan dengan desain ke 2 memiliki nilai kekakuan yang paling tinggi yaitu dengan nilai $20,16 \times 10^{6} \mathrm{~N}$. Balok beton dengan menggunakan baja tulangan mendapatkan nilai kekakuan dengan nilai $16,02 \times 10^{6} \mathrm{~N}$ lebih kecil dari baja ringan desain 2 , balok beton dengan menggunakan baja ringan dengan desain 3 memiliki nilai kekakuan $11,203 \times 10^{6} \mathrm{~N}$ lebih kecil dari nilai kekakuan baja tulangan dan yang terakhir balok beton dengan menggunakan baja ringan desain 1 memiliki nilai yang terkecil yaitu $11,92 \times 10^{6} \mathrm{~N}$.

\section{KESIMPULAN}

1. Nilai kuat lentur rata-rata pada sampel Baja Ringan kanal C desain B yaitu 11,816 Mpa dan baja tulangan didapat nilai kuat lentur 9,993 Mpa,

2. Niai kekakuan rata-rata pada sampel Baja ringan kanal $\mathrm{C}$ dengan design $\mathrm{B}$ mendapat nilai tertinggi dengan nilai $20,16 \times 10^{6}$ dan sampel baja tulangan didapat nilai $16,02 \times 10^{6}$ sehingga dengan hasil yang telah didapat ini maka baja ringan kanal $\mathrm{C}$ dapat digunakan sebagai alternativ pengganti pada tulangan baja tulangan kususnya pada balok dengan dimensi $15 \times 15 \mathrm{~cm}$.

\section{DAFTAR PUSTAKA}

[1] A. Suandi, Analisa Kuat Lentur Balok Beton Bertulang dengan Menggunakan Profil Baja Ringan Tulangan.

Universitas
Muhammadiyah Metro, 2020.

[2] K. Budi Hastono, "Penggunaan Baja Ringan (Cold-Formed) Type Hollow Sebagai Tulangan Pada Balok Beton Bertulang Dalam Memikul Beban Lentur," UPN Jatim, no. April, pp. 21-38, 2014.

[3] M. S. Muslimin and A. P. Putri, "Uji lentur balok beton bertulang baja ringan dengan skema tulangan tunggal," vol. 11, no. 1, pp. 171-180, 2021.

[4] Wibisono, Penambahan Perkuatan Lentur Balok Beton Bertulang dengan Penambahan Pelat Baja. Universitas Islam Indonesia, 2017.

[5] B. S. Nasional, "Baja tulangan beton (SNI 2052:2017)," Standar Nas. Indones., p. 15, 2017.

[6] A. H. Tumcala, Tinjauan Kinerja Balok Beton Bertulang Tampang Empat Persegi Panjang dengan Tulangan dari Profil Baja Ringan. 2017.

[7] SK SNI S-02-1994-03, Spesifikasi Agregat Halus untuk Pekerjaan Adukan dan Plesteran dengan Bahan Semen. 2002.

[8] SNI 4431-2011, "Cara uji kuat lentur beton normal dengan dua titik pembebanan," Badan Standar Nas. Indones., p. 16, 2011.

[9] Y. Oktarinata, I. Gunawan, and D. F. Manalu, "Kapasitas Lentur Balok Komposit Beton Dengan Baja," FROPIL (Forum Prof. Tek. Sipil), vol. 8, no. 2, pp. 76-84, 2021.

[10] U. S. Utara, "BAJA RINGAN PROFIL U Disusun oleh : LOLIANDY," 2014.

[11] SK SNI 15-1991-03, "Tata Cara Perhitungai Struktur Beton Untuk Bangunan Gedung," Sk Sni T151991-03, p. 520, 1991.

[12] A. Godean, S. Optimasi, P. Campurannya, P. Rekayasa, and B. Substitusi, "Pemanfaatan Apg (Agregat Pecahan Genteng) Asal 
Jurnal Teknika Sains

Volume 06, Nomor 01, 2021

Godean Serta Optimasi Proporsi

Campurannya Pada Rekayasa Beton

Substitusi," J. Tek. Sipil dan Perenc., vol. 10, no. 1, pp. 47-56, 2008. 